\title{
CZYNNIKI I BARIERY ROZWOJU A PERYFERYJNOŚĆ WOJEWÓDZTWA LUBUSKIEGO
}

\author{
Przemysław Szczuciński \\ Wydział Ekonomiczny Akademii im. Jakuba z Paradyża w Gorzowie Wlkp. \\ Dziekan Wydziału: dr Małgorzata Trocka
}

\begin{abstract}
Słowa kluczowe: województwo lubuskie, region peryferyjny, rozwój społeczno-ekonomiczny, system osadniczy, infrastruktura, analiza statystyczna

Key words: Lubuskie Voivodeship, peripheral region, social and economic development, settlement system, infrastructure, statistical analysis

S y n o p s i s. Do podstawowych cech współczesnej gospodarki należą zróżnicowanie przestrzenne i jej zmienność w czasie. Obserwuje się, że jedne regiony i kraje rozwijają się szybciej, inne wolniej. Ramy teoretyczne badania ich rozwoju określa koncepcja peryferyjności regionalnej. Nawiązując do tej koncepcji, w artykule poddano ocenie możliwości rozwoju województwa lubuskiego. W badaniach empirycznych uwzględniono 39 wskaźników diagnostycznych opisujących następujące grupy uwarunkowań: położenie geograficzne i system osadniczy, gospodarkę i jej strukturę, czynniki demograficzno-społeczne, infrastrukturę regionu. Wykorzystując dane za 2014 rok, przeprowadzono analizę rozwoju województwa na tle gospodarki polskiej z uwzględnieniem wybranych aspektów rozwoju obszarów wiejskich. Wyniki przeprowadzonych badań wskazują, że w wielu przypadkach województwo lubuskie charakteryzują procesy typowe dla regionów peryferyjnych.
\end{abstract}

\section{WPROWADZENIE}

W teorii ekonomiki regionalnej region rozumiany jest jako system ekonomiczno-przestrzenny obejmujący wyodrębniony z otoczenia fragment przestrzeni trwale zamieszkany, zagospodarowany i kontrolowany przez określoną społeczność [Kosiedowski 2001, s. 19]. Aplikacyjne podejście do pojęcia regionu ekonomicznego wymaga jednak ścisłego wyznaczenia jego granic. W tej kwestii często wykorzystuje się podział terytorialno-administracyjny państwa i odnosi pojęcie regionu ekonomicznego do poziomu województw. Wchodzące w ich skład jednostki niższego szczebla, tj. powiaty i gminy są nazywane jednostkami lokalnymi.

Funkcjonowanie i rozwój regionów zależy od wielu różnych czynników geograficznych, przyrodniczych, osadniczych, społecznych, gospodarczych i innych, które warunkują procesy ich rozwoju. Powodują one, że regiony jako systemy ekonomiczno-przestrzenne charakteryzują się zróżnicowanym poziomem rozwoju. Ze względu na poziom rozwoju społeczno-ekonomicznego regionów wyróżnia się regiony lepiej i słabiej rozwinięte. Wskazuje się też, że te pierwsze stanowią swoiste centra rozwoju, a te drugie również ze względu 
na ich położenie geograficzne pozostają często w znaczącym opóźnieniu. Regiony takie określa się mianem regionów peryferyjnych lub problemowych [Bajerski 2008, s. 159].

Zgodnie z zasadami polityki spójności Unii Europejskiej (UE) na lata 2014-2020, do regionów peryferyjnych (mniej rozwiniętych) zalicza się te regiony, których produkt krajowy brutto (PKB) na mieszkańca wynosi mniej niż 75\% średniego poziomu w krajach UE-27 [KE 2011, s. 15]. Do regionów takich należy również województwo lubuskie.

Celem artykułu jest analiza empiryczna uwarunkowań wpływających na peryferyjność województwa lubuskiego oraz wskazanie jego możliwości rozwojowych na tle gospodarki polskiej. Podstawy teoretyczne analizy stanowi koncepcja rozwoju regionów peryferyjnych.

\section{PERYFERYJNOŚĆ REGIONU W UJĘCIU TEORETYCZNYM I PRAKTYCZNYM}

Peryferyjność regionów postrzegać można w różnych aspektach. Jednym z podstawowych czynników jest położenie geograficzno-komunikacyjne regionu [Miszczuk 2013, s. 10 i n.]. Według tego kryterium, za region peryferyjny uznaje się obszar oddalony od centrów życia administracyjnego i społeczno-gospodarczego oraz trudno dostępny komunikacyjnie, gdzie koszt pokonania odległości od centrum jest wysoki. Istotną cechą peryferyjności jest także brak wyższych pięter hierarchicznych sieci osadniczej.

Drugim czynnikiem decydującym o peryferyjności jest poziom rozwoju społeczno-ekonomicznego regionów, który najczęściej jest charakteryzowany za pomocą wielkości PKB na mieszkańca. Obok niskiej wartości tego wskaźnika, jako cechę specyficzną regionów peryferyjnych wymienia się także występującą strukturę zatrudnienia. Dla obszarów peryferyjnych charakterystyczny jest duży udział pracujących w takich sektorach, jak: rolnictwo, rybołówstwo, leśnictwo, górnictwo. Wynika to z reguły z występującej specjalizacji surowcowej regionu, którą zazwyczaj cechuje niska wartość dodana. Wskazuje się także, że obszar peryferyjny poddawany jest często „wymywaniu” zasobów pracy, któremu sprzyjają nierówności płacowo-dochodowe pomiędzy nim a centrum rozwoju.

Trzecim z podstawowych czynników peryferyjności jest niska gęstość zaludnienia i wiążący się z nią spadek liczby ludności. Na dokonującą się polaryzację przestrzeni wpływa w tym względzie z jednej strony urbanizacja i koncentracja ludności w największych ośrodkach miejskich oraz przesiedlanie się jej na tereny sąsiadujące. Z drugiej strony zauważyć można wyludnianie się obszarów peryferyjnych, szczególnie o charakterze wiejskim, położonych z dala od dużych miast. Następstwem tych procesów jest odpływ młodych ludzi powodujący zmniejszanie się przyrostu naturalnego, co niekorzystnie wpływa na rozwój tych obszarów także w dłuższym czasie. Przyczyn tego zjawiska upatrywać można w takich motywach, jak: chęci znalezienia satysfakcjonującej pracy, uzyskania lepszych warunków wynagrodzenia oraz polepszenia standardów mieszkaniowych. W efekcie na obszarach peryferyjnych zaobserwować można zmniejszanie się zasobów pracy, odpływ aktywnych i wykształconych ludzi oraz proces starzenia się społeczności lokalnej i regionalnej. Niekorzystne konsekwencje tego procesu skutkować mogą także dla systemu finansów publicznych poprzez spadek dochodów przy jednoczesnym wzroście wydatków oraz dla systemu zabezpieczeń społecznych i zdrowotnych.

Jednym ze skutków zmniejszania się kapitału ludzkiego jest też występowanie zjawiska peryferyjności kulturowej, wyrażającej się w niskim poczuciu tożsamości terytorialnej, rozumianej jako emocjonalny stosunek ludności do tego terytorium. Często zjawisku temu towarzyszy także mała reprezentacja elit politycznych w centralnych organach państwa oraz 
mały zakres efektywnie wykonywanych kompetencji przez władze regionalne, co wynika z niskiego potencjału finansowego, będącego rezultatem peryferyjności ekonomicznej i społeczno-demograficznej.

Koncepcje opisujące rozwój regionów peryferyjnych podzielić można na dwie grupy [Grosse 2007, s. 28 i n.]. Pierwsza z nich nawiązuje do rozwoju egzogenicznego opartego na czynnikach zewnętrznych. Podstawę tych koncepcji stanowi przekonanie, że nie można uruchomić procesów rozwoju regionów peryferyjnych jedynie na bazie ich wewnętrznego potencjału. Zakładają one bowiem, że jest on niewystarczający i uśpiony, więc konieczne jest sięgnięcie po publiczne lub prywatne inwestycje zewnętrzne oraz transfer zewnętrznych doświadczeń i instytucji.

Druga grupa koncepcji nawiązuje do rozwoju endogenicznego, tj. opartego w głównej mierze na czynnikach wewnętrznych. Podstawę tego podejścia stanowi przeświadczenie, że tylko wywołanie tego typu procesów pozwala na samodzielny, długookresowy i stabilny rozwój. Rozwój endogeniczny pozwala uniknąć regionom peryferyjnym zależności od centrów krajowych oraz rozwoju opierającego się wyłącznie na transferze inwestycji o charakterze socjalnym i politycznym. Obecnie koncepcje rozwoju endogenicznego nie odrzucają potrzeby wsparcia obszarów peryferyjnych przez inwestycje zewnętrzne. Uznają także potrzebę otwarcia regionów na zewnętrznych kooperantów i rynki zbytu. Wskazują jednak na konieczność dostosowania transferowanych inwestycji, środków i doświadczeń do lokalnych warunków i potrzeb rozwojowych.

W analizie regionalnej istotnym zagadnieniem jest także określenie wskaźników pomiarowych rozwoju gospodarczego regionów. Ważniejsze propozycje metodyczne i wyniki badań empirycznych w tym zakresie zostały przedstawione w pracach Aleksandra Zeliasia [2000], Zygmunta Szymli [2000], Anny Maliny [2004], Danuty Strahl [2006] i Janusza Korola [2007]. Wyróżnić można kilka ujęć grupowania wskaźników w grupy tematyczne. Ogólny podział obejmuje wskaźniki: ekonomiczne, społeczne i środowiskowe. Rozpatrując je głębiej, wymienić można wskaźniki opisujące: położenie geograficzne regionu, bazę ekonomiczną miast, strukturę gospodarki regionalnej, zasoby demograficzne, kapitał ludzki, infrastrukturę drogową i techniczną, kapitał finansowy, zaplecze naukowo-technologiczne, rozwój sektora małych i średnich przedsiębiorstw (MSP), rynek pracy, rolnictwo, jakość życia, regionalny ekosystem.

Przedstawiane w literaturze wskaźniki rozwoju regionalnego stanowić mogą także podstawę identyfikacji problemów rozwoju regionów peryferyjnych. Na potrzeby realizacji celu badań wzięto pod uwagę: położenie geograficzne i system osadniczy, gospodarkę i jej strukturę, uwarunkowania demograficzno-społeczne oraz infrastrukturę regionalną. W odniesieniu do tych cech w analizie rozwoju województwa lubuskiego wykorzystano łącznie 39 wskaźników pomiarowych. Dane statystyczne przedstawiają stan za 2014 rok.

\section{POŁOŻENIE GEOGRAFICZNE I SYSTEM OSADNICZY}

Do podstawowych uwarunkowań rozwoju regionu należą jego położenie geograficzne, warunki naturalne i system osadniczy [zob. Kuciński 2015, s. 347]. Województwo lubuskie jest położone w zachodniej części Polski przy granicy z Niemcami. Od północy region sąsiaduje z województwem zachodniopomorskim, od wschodu z wielkopolskim i od południa z dolnośląskim. Przez terytorium województwa lubuskiego przebiegają ważne szlaki komunikacyjne Berlin-Poznań-Warszawa, Szczecin-Wrocław oraz Berlin-Wrocław (drogi 
A2, A18 i S3). Najważniejsze przejścia graniczne znajdują się w: Kostrzynie, Słubicach, Gubinie, Świecku i Olszynie.

Ze względu na wielkość i liczbę ludności region lubuski jest jednym z mniejszych. Powierzchnia województwa obejmuje 13988 km², na których w 2014 r. zamieszkiwało 1,020 tys. osób (2,65\% ogółu ludności w kraju). Stolicami województwa są Gorzów Wielkopolski, który jest siedzibą wojewody, oraz Zielona Góra, siedziba sejmiku wojewódzkiego. W podziale administracyjnym wydzielonych jest 12 powiatów ziemskich i 2 grodzkie (stolice regionu) oraz 83 gminy. Wśród gmin: 9 to gminy miejskie, 33 miejsko-wiejskie, 41 wiejskie.

System osadniczy regionu to zbiór powiązanych ze sobą funkcjonalnie jednostek osadniczych występujących na danym obszarze. System ten w województwie lubuskim tworzą 42 miasta i 1023 wsie. Największymi ośrodkami są liczące około 120 tys. mieszkańców miasta Gorzów Wielkopolski i Zielona Góra. Są to miasta o znaczeniu krajowym i wojewódzkim, mające tworzyć zarazem dwubiegunowy układ przenoszenia rozwoju gospodarczego na obszar całego regionu [zob. Strategia rozwoju... 2012]. Pozostałe większe ośrodki miejskie to: Nowa Sól i Żary (39 tys. mieszkańców), Żagań (26 tys. mieszkańców) i Świebodzin (22 tys. mieszkańców).

Wskaźniki charakteryzujące sieć osadniczą regionu w 2014 r. przedstawiono w tabeli 1. Punkt odniesienia stanowiła gospodarka Polski, co umożliwiło określenie profilu województwa na tle średniej krajowej. Metodę tę zastosowano np. w pracy Stanisława Korenika [1999, s. 125].

W województwie na $1000 \mathrm{~km}^{2}$ przypadają 3,0 miasta, gdy średnio $\mathrm{w}$ kraju jest to 2,9 miasta [BDL 2016]. Na poziomie zbliżonym do przeciętnego dla kraju kształtował się również odsetek ludności mieszkającej w miastach. W regionie było to $63,1 \%$, a ogólnie w

Tabela 1. Wskaźniki osadnicze województwa lubuskiego na tle średniej krajowej za $2014 \mathrm{r}$.

\begin{tabular}{lc}
\hline Wskaźnik & Polska = 100 \\
\hline Gęstość zaludnienia na km² & 59,3 \\
Liczba miast na 1000 km² & 103,4 \\
Powierzchnia lasów [\%] & 169,3 \\
Udział ludności w miastach [\%] & 104,6 \\
Udział ludności na wsi [\%] & 92,9 \\
$\begin{array}{l}\text { Udział ludności w miastach } \\
\text { powyżej 50 tys. mieszkańców [\%] }\end{array}$ & 65,2 \\
\hline
\end{tabular}

Źródło: opracowanie własne. Polsce odsetek ten wynosił $60,3 \%$. Udział ludności zamieszkującej wieś wynosił 36,9\% i był też podobny, jak dla całego kraju. Wyraźnie niższa niż średnia krajowa była jednak gęstość zaludnienia w regionie. Wynosiła jedynie 72,9 osoby na $\mathrm{km}^{2}$, czyli 59,2\% średniej krajowej. Wynika to z największego w Polsce udziału lasów w powierzchni regionu, który sięga aż 50,8\%. Czynnikiem wpływającym na mniejszą gęstość zaludnienia jest też struktura miast w regionie. Oprócz Gorzowa Wielkopolskiego i Zielonej Góry pozostałe miasta liczą poniżej 50 tys. mieszkańców i stąd też mniejszy niż ogółem w Polsce odsetek ludności w miastach powyżej tej wielkości. W regionie odsetek ten wynosił 23,8\%, a w Polsce ogółem sięgał 36,5\%.

Istotne zagadnienie dla harmonijnego rozwoju regionu, obok roli, jaką odgrywają stolice regionu, stanowi zatem także problematyka funkcjonowania oraz rozwoju małych i średnich miast. 


\section{GOSPODARKA I JEJ STRUKTURA}

W województwie lubuskim aktywną działalność prowadziło 45817 podmiotów [GUS $2015 \mathrm{~b}]^{1}$. W przeliczeniu na 1000 mieszkańców było to 44,9 przedsiębiorstw. Poziom ten był zbliżony do średniej krajowej (93,7\%). Dość liczna była przy tym grupa podmiotów z udziałem kapitału zagranicznego. Liczba tych jednostek wynosiła 7,0 na 1000 mieszkańców, czyli 102,2\% średniej krajowej [GUS 2015a]. Ze względu na bliskość granicy największy udział stanowił kapitał niemiecki. Jego udział to 22,7\% ogółu kapitału zainwestowanego w regionie. W tabeli 2. przedstawiono wskaźniki na tle kraju [por. Szymla 2000, s. 66].

Tabela 2. Wskaźniki gospodarcze województwa lubuskiego na tle średniej krajowej za 2014 r.

\begin{tabular}{lr}
\hline Wskaźnik & Polska =100 \\
\hline Liczba aktywnych przedsiębiorstw na 1000 mieszkańców & 93,7 \\
Liczba spółek z udziałem kapitału zagranicznego na 10 tys. mieszkańców & 102,2 \\
Liczba pracujących na 1000 mieszkańców & 87,5 \\
Udział pracujących w rolnictwie [\%] & 67,3 \\
Udział pracujących w przemyśle [\%] & 120,8 \\
Udział pracujących w usługach [\%] & 100,0 \\
Wartość brutto środków trwałych na mieszkańca [tys. zł] & 101,5 \\
Liczba gospodarstw rolnych na 1000 mieszkańców & 56,0 \\
Przeciętna powierzchnia gospodarstwa rolnego powyżej 1 ha & 175,8 \\
Liczba ciągników na 100 ha powierzchni użytków rolnych & 49,0 \\
Przeciętne miesięczne wynagrodzenie brutto [zł] & 85,5 \\
Liczba noclegów udzielonych turystom na 1000 mieszkańców & 72,0 \\
\hline
\end{tabular}

Źródło: opracowanie własne.

Miarą posiadanego kapitału rzeczowego jest wartość brutto środków trwałych. Biorąc pod uwagę przedsiębiorstwa, gospodarstwa rolne oraz pozostałe podmioty gospodarki, wynosiła ona $87721,6 \mathrm{mln}$ zł. W przeliczeniu na mieszkańca województwa było to 86 tys. zł. Dla gospodarki polskiej wartość wskaźnika kształtowała się na poziomie 84,7 tys. zł. Stwierdzić zatem można, że na tle kraju gospodarka regionu dysponuje potencjałem wytwórczym (maszyny, urządzenia, budynki, środki transportu) relatywnym do jej wielkości.

Pomimo względnie wysokich wskaźników przedsiębiorczości i majątku trwałego, poziom zatrudnienia był niższy niż ogólnie w kraju. W przeliczeniu na 1000 mieszkańców w gospodarce regionu w 2014 r. pracowało 323,9 osób. Średnia krajowa wynosiła 370,0 osób. Wynika to z mniejszej wielkości przedsiębiorstw w regionie niż generalnie w kraju. Ogólnie liczba pracujących na podmiot w województwie lubuskim wynosiła 4,3 osoby, gdy w kraju było to 5,0 osób. Udział małych i średnich przedsiębiorstw w liczbie pracujących w regionie sięgał $79 \%$, a dużych $21 \%$. Dla porównania w gospodarce ogółem udział dużych przedsiębiorstw wynosił 30,8\%.

W strukturze zatrudnienia wyższy niż w kraju był odsetek pracujących w przemyśle. Odsetek ten w regionie wynosił 31,9\%, natomiast średnio dla kraju 26,4\%. Podobny jak

1 Dane te dotyczą przedsiębiorstw faktycznie prowadzących działalność gospodarczą. Ich podstawą są wyniki badań GUS obejmujące pełne badania podmiotów o liczbie pracujących 10 i więcej osób oraz badania reprezentacyjne podmiotów do 9 pracujących. Są to bardziej wiarygodne dane niż dane z rejestru REGON obejmujące wiele podmiotów, które zakończyły lub zawiesiły działalność albo nie rozpoczęły jej po zarejestrowaniu i nie zgłosiły tego faktu do GUS. 
w kraju był udział osób pracujących w usługach (56,9\%), niższy w rolnictwie 11,3\% względem 16,8\% [GUS 2016a]. W produkcji sprzedanej przemysłu największy udział miały takie działy, jak: produkcja pojazdów samochodowych, przyczep i naczep 15,7\%, wyrobów z drewna, wikliny i korka $11,3 \%$, artykułów spożywczych 8,9\%, wyrobów z papieru 8,3\%, wyrobów z metali 6,9\% [US w Zielonej Górze 2015].

Biorąc pod uwagę rolnictwo, mniejsza była też w regionie liczba gospodarstw niż ogólnie w Polsce. Działalność tę w 2014 r. prowadziło 21256 gospodarstw, tj. 20,8 na 1000 mieszkańców. Dla całej gospodarki narodowej wskaźnik wynosił 37,1 gospodarstw na 1000 mieszkańców. Wynikało to z mniejszej powierzchni użytków rolnych w województwie lubuskim (40,4\%) niż w kraju (59,9\%). Wyższa była jednak przy tym niż średnia krajowa przeciętna powierzchnia gospodarstw indywidualnych. W grupie gospodarstw powyżej 1 ha było to 16,7 ha w porównaniu do 9,8 ha. Słabe było jednak wyposażenie gospodarstw w maszyny rolnicze. Świadczyć o tym może liczba ciągników względem areału użytków rolnych. W regionie było to 4,8 ciągnika, natomiast ogólnie w kraju 9,8 ciągnika na 100 ha.

Stan rozwoju gospodarki znajduje także odzwierciedlenie w wysokości dochodów mieszkańców. W tym względzie podstawowym wskaźnikiem jest przeciętne miesięczne wynagrodzenie brutto. W województwie lubuskim w 2014 r. wynosiło ono 3 425,40 zł. Relatywnie wskaźnik wynagrodzeń nie był więc wysoki, gdyż stanowił 85,5\% średniej dla całego kraju.

Jednym z istotnych aspektów jest także rozwój sektora turystyki. W badanym roku z bazy turystycznej w regionie skorzystało 595301 turystów, którym udzielono 1201907 noclegów. W przeliczeniu na 1000 mieszkańców było to 1178 noclegów i wielkość ta kształtowała się na poziomie $72 \%$ średniej krajowej. Stopień wykorzystania bazy noclegowej w regionie $(25,7 \%)$ był niższy niż przeciętnie w Polsce $(34,8 \%)$. Region ma wiele walorów, takich jak: duża lesistość, występujące jeziora (łącznie 519), zagęszczenie szlaków turystycznych $\left(45,2\right.$ na $\left.100 \mathrm{~km}^{2}\right)$ oraz liczne obiekty wpisane do rejestru zabytków $(28,4$ na $100 \mathrm{~km}^{2}$ ). Można je wykorzystać na rzecz rozwoju różnych form turystyki przyrodniczej i rekreacyjno-wypoczynkowej [zob. US w Zielonej Górze 2016, s. 114].

\section{UWARUNKOWANIA DEMOGRAFICZNO-SPOŁECZNE}

Do podstawowych uwarunkowań rozwoju regionu obok czynników gospodarczych należą także czynniki demograficzno-społeczne. Zauważyć można podobne nasilenie ruchu naturalnego ludności w województwie lubuskim i w kraju. Opisują to wskaźniki urodzeń i zgonów. Według danych, w 2014 r. liczba urodzeń wyniosła 9 716, liczba zgonów 9 553. Było to odpowiednio 9,5 i 9,4 osoby na 1000 mieszkańców w regionie, co stanowiło odpowiednio 96,9 i 95,9\% średniej krajowej. Pewna przewaga urodzeń nad zgonami wskazuje, że zarysowuje się tendencja dodatniego przyrostu naturalnego, który wynosił 0,1 osób na 1000 mieszkańców.

Typowa dla kraju jest także w regionie struktura ludności według wieku. Udział ludności w wieku przedprodukcyjnym wynosił $16,3 \%$, w produkcyjnym $63,8 \%$, w poprodukcyjnym 18,0\%. Wskaźniki na tle kraju przedstawiono w tabeli 3. [por. Szymla 2000, s. 65].

Cechą charakterystyczną dla regionu okazuje się zaś dość duża dynamika ruchu wędrówkowego ludności. Liczba zameldowań i wymeldowań na pobyt stały międzywojewódzkich i zagranicznych wynosiła odpowiednio 3448 i 4771 osób. Wskaźniki kształtowały się na poziomie 3,4 i 4,7 osób na 1000 mieszkańców i zdecydowanie przekraczały średnią krajową. Silniejsza była przy tym tendencja do odpływu ludności niż do jej napływu. Na tle kraju wartość wskaźnika sięgała nawet 146,9\% i było to zjawisko niekorzystne. 
Tabela 3. Wskaźniki demograficzno-społeczne województwa lubuskiego na tle średniej krajowej za 2014 r.

\begin{tabular}{lc}
\hline Wskaźnik & Polska = 100 \\
\hline Liczba urodzeń na 1000 mieszkańców & 96,9 \\
Liczba zgonów na 1000 mieszkańców & 95,9 \\
Zameldowania międzywojewódzkie i zagraniczne na 1000 mieszkańców & 119,4 \\
Wymeldowania międzywojewódzkie i zagraniczne na 1000 mieszkańców & 144,4 \\
Udział ludności w wieku przedprodukcyjnym [\%] & 101,7 \\
Udział ludności w wieku produkcyjnym [\%] & 101,3 \\
Udział ludności w wieku poprodukcyjnym [\%] & 94,7 \\
Stopa bezrobocia rejestrowanego [\%] & 109,6 \\
Udział bezrobotnych długotrwale wśród bezrobotnych ogółem [\%] & 82,5 \\
Liczba studentów na 1000 mieszkańców & 46,1 \\
Uczestnicy imprez na obszarach wiejskich na 1000 mieszkańców & 45,6 \\
\hline
\end{tabular}

Źródło: opracowanie własne.

Do ważnych aspektów rozwoju regionu należy także problem bezrobocia. Liczba zarejestrowanych bezrobotnych w 2014 r. w regionie wynosiła 47115 osób. Stopa bezrobocia kształtowała się na poziomie $12,5 \%$, a w Polsce wynosiła $11,4 \%{ }^{2}$. Wskazuje to na większą trudność w znalezieniu pracy niż ogólnie w kraju. Biorąc jednak pod uwagę odsetek bezrobotnych pozostających bez pracy powyżej 12 miesięcy, który był z kolei niższy niż średnia krajowa, zauważyć należy względnie większą „rotację” w strukturze zjawiska. Jednym z czynników wpływających na ten stan był odpływ ludności z regionu. Potwierdzenie występujących związków wymaga jednak dalszych pogłębionych badań.

Wśród uwarunkowań demograficzno-społecznych zasadniczy czynnik stanowią zasoby wiedzy zawarte $\mathrm{w}$ danym społeczeństwie ${ }^{3}$. Jednym $\mathrm{z}$ podstawowych tego mierników jest liczba studentów szkół wyższych. W regionie lubuskim wynosiła ona 17,3 na 1000 mieszkańców. Wskaźnik w porównaniu do średniej krajowej kształtował się na poziomie $46,1 \%$ i był najniższy wśród wszystkich regionów w Polsce.

Istotnym elementem rozwoju jest także uczestnictwo ludności mieszkającej na obszarach wiejskich w życiu społecznym regionu. W tym zakresie duże znaczenie mają działające na tych obszarach instytucje i ośrodki kultury. Ich działalność pozwala zaspokoić potrzeby społeczne, artystyczne, sportowe, rozrywkowe, a także samokształcenia. Instytucje te wzmacniają integrację społeczności lokalnej i rozwijają aktywność obywatelską [GUS 2016b, s. 189]. Jednym z ważniejszych wskaźników jest liczba uczestników imprez masowych organizowanych na obszarach wiejskich. W 2014 r. w wojewódzkie lubuskim było to 291 osób na 1000 mieszkańców, średnio w Polsce zaś 638. Wartość wskaźnika wynosiła jedynie 45,6\%. Należy uznać to, oprócz niskiej liczby studentów, za jedną z barier rozwojowych regionu i czynnik jego peryferyjności.

2 W końcu maja 2016 r. w województwie lubuskim zaobserwowano spadek liczby bezrobotnych. Ich liczba zmniejszyła się do 35,2 tys., natomiast stopa bezrobocia do 9,5\%. Pozostaje ona jednak cały czas wyższa od średniej krajowej wynoszącej 9,1\%.

3 W literaturze funkcjonuje nawet pojęcie kapitału ludzkiego rozumiane jako rezultat inwestycji w oświatę i wykształcenie oraz innych nakładów wpływających na jakość zasobów ludzkich, np. wydatków ponoszonych na ochronę zdrowia, ochronę środowiska, rozwój kultury itp. Wskazuje się zarazem, że jakość kapitału ludzkiego jest w dużej mierze pochodną wykształcenia, a im jest ona wyższa, tym większe są możliwości rozwojowe gospodarki [zob. Kuciński 2015, s. 111]. 


\section{INFRASTRUKTURA DROGOWA, NAUKOWO-BADAWCZA I INFORMATYCZNA}

Rozwój gospodarki regionu, przepływy ludzi, dóbr i informacji uwarunkowane są także przez stworzenie odpowiedniej infrastruktury w transporcie i łączności [zob. Domański 2006, s. 26]. W ten sposób miasta i regiony oddziałują na bliższe i dalsze otoczenie. Istotnym elementem szeroko rozumianej infrastruktury jest również zaplecze badawczo-rozwojowe w regionie. Tak rozumiana infrastruktura stanowi bazę materialną funkcjonowania życia gospodarczego i społecznego w regionie. Wskaźniki dotyczące tego obszaru przedstawiono w tabeli 4. [por. Szymla 2000, s. 66].

Tabela 4. Wskaźniki infrastrukturalne województwa lubuskiego na tle średniej krajowej za 2014 r.

\begin{tabular}{lc}
\hline Wskaźnik & Polska = 100 \\
\hline Liczba jednostek B+R na 100 tys. mieszkańców & 51,0 \\
Wartość aparatury naukowo-badawczej na mieszkańca [zł] & 7,2 \\
Linie kolejowe na $100 \mathrm{~km}^{2}$ & 106,5 \\
Drogi ekspresowe i autostrady na 100 km² & 172,4 \\
Udział twardych dróg powiatowych i gminnych w ogóle tych dróg [\%] & 76,5 \\
Produkcja energii elektrycznej na mieszkańca [MWh] & 59,3 \\
Udział przedsiębiorstw mających dostęp do Internetu [ \%] & 99,4 \\
Ludność korzystająca z sieci wodociągowej na obszarach wiejskich [\%] & 105,2 \\
Ludność korzystająca z sieci kanalizacyjnej na obszarach wiejskich [\%] & 91,4 \\
Ludność korzystająca z sieci gazowej na obszarach wiejskich [\%] & 59,3 \\
\hline
\end{tabular}

Źródło: opracowanie własne.

Infrastrukturę drogową tworzyło w 2014 r. w województwie lubuskim łącznie 14830 km dróg, w tym 8647 km dróg o nawierzchni twardej. Spośród nich dość dobrze rozwinięta jest sieć dróg ekspresowych i autostrad. Ich długość wynosiła $232 \mathrm{~km}$, co daje w przeliczeniu wysoki wskaźnik na tle kraju 1,66 na $100 \mathrm{~km}^{2}$. Pozwala to na dobre skomunikowanie stolic województwa oraz z regionami przyległymi. Słabiej wypada jakość dróg wewnętrznych w regionie, czyli dróg wojewódzkich, powiatowych i gminnych. Udział dróg gminnych o nawierzchni twardej był niski i wynosił jedynie 49,7\%, gdy średnia dla kraju wynosiła 65,0\%. Podobne było natomiast zagęszczenie sieci kolejowej. Wielkość wskaźnika wynosiła $6,6 \mathrm{~km}$ na $100 \mathrm{~km}^{2}$.

Sieć elektro-energetyczną w regionie tworzą: sieci wysokiego napięcia $1243 \mathrm{~km}$, średniego napięcia $8885 \mathrm{~km}$, niskiego napięcia $11131 \mathrm{~km}$ i przyłącza $3030 \mathrm{~km}$. Moc wytwórcza i produkcja energii elektrycznej były jednak mniejsze niż ogólnie w kraju. Ta ostatnia wynosiła 2503,6 GWh, czyli w przeliczeniu na mieszkańca 59,3\% średniej krajowej. Jest to wielkość niewystarczająca do zapewnienia zasilania w warunkach szczytowego zapotrzebowania mocy i powoduje konieczność dostaw energii z rezerw Krajowego Systemu Elektroenergetycznego poprzez GSZ Leśniów i GSZ Gorzów [Strategia energetyki... 2013, s. 89].

Następnym z elementów infrastruktury jest zaplecze badawczo-rozwojowe. W województwie lubuskim działalność tę w 2014 r. prowadziło 47 jednostek. W przeliczeniu na 100 tys. mieszkańców było to 4,6 jednostek. W porównaniu ze średnią krajową liczba ta wynosiła tylko 51,0\%. Bardzo niska była także wartość aparatury badawczej $(27,1$ zł na 
mieszkańca i zaledwie 7,2\% średniej krajowej). Bardziej zadawalająca jest dostępność do sieci internetowej. Dostęp ten posiadało 92,5\% przedsiębiorstw i była to wielkość na poziomie standardów krajowych. Jednak słaby rozwój zaplecza badawczo-rozwojowego jest jedną z istotnych barier rozwoju regionu.

W rozwoju regionu ważnym zagadnieniem jest także odpowiednie zagospodarowanie infrastrukturalne na obszarach wiejskich. Charakteryzują je wskaźniki dostępności sieci wodociągowej, kanalizacyjnej i gazowej. Na tle kraju relatywnie wysoki jest odsetek ludności korzystającej z sieci wodociągowej. Wynosił on w regionie 88,7\%, czyli 105,2\% średniej krajowej. Mniejszy był odsetek ludności korzystającej z sieci kanalizacyjnej 34,1\% i gazowej $13,3 \%$. W porównaniu do standardów krajowych pierwszy ze wskaźników wynosił 91,4\% średniej, natomiast drugi tylko 59,3\%. Wskazuje to także na pewne braki $\mathrm{w}$ rozwoju infrastruktury na obszarach wiejskich $\mathrm{w}$ regionie.

\section{POZIOM I DYNAMIKA PKB WOJEWÓDZTWA NA TLE INNYCH WOJEWÓDZTW}

Swoistą wypadkową oddziaływania różnych czynników na rozwój regionu i zarazem jednym z głównych jego mierników jest wielkość produktu krajowego brutto. Województwo lubuskie w tym względzie uznać należy za region o gorszych wynikach gospodarczych od innych województw. Wniosek ten wynika z analizy dynamiki PKB w okresie 1999-2014 w porównaniu do jego poziomu wyjściowego z roku 1999. Punktem odniesienia była średnia dla wszystkich województw. Na jej podstawie dokonano ich podziału na cztery grupy rozwojowe [zob. Łaźniewska 2013, s. 53]. Ilustrację graficzną przedstawiono na rysunku 1.

Grupę A stanowią województwa relatywnie bogate o silnej gospodarce. Są to województwa: mazowieckie, wielkopolskie i dolnośląskie. Ich PKB na mieszkańca jest wyraźnie wyższy od średniej dla wszystkich województw. Przekraczają również średnie

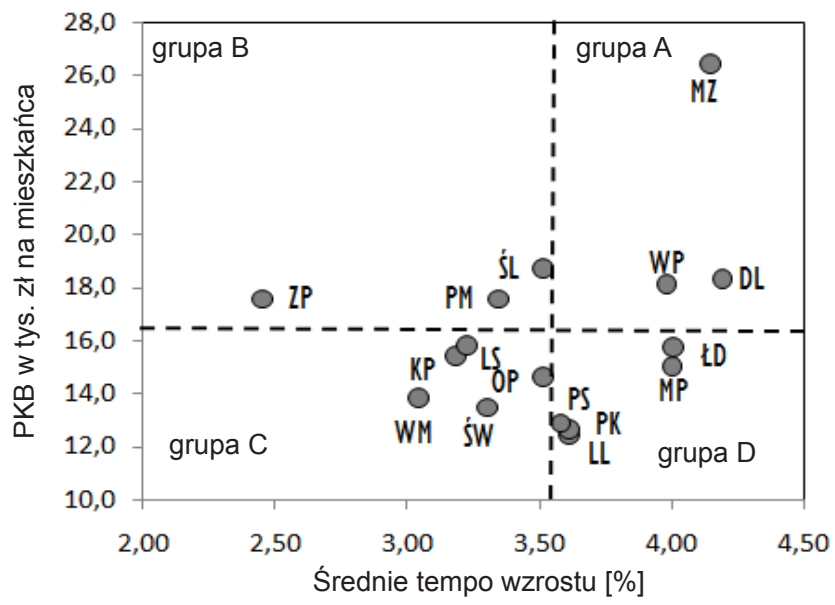

Rysunek 1. Poziom PKB w 1999 roku i średnie tempo wzrostu w latach 1999-2014 w województwie lubuskim na tle innych województw

Źródło: opracowanie własne. 
tempo wzrostu w badanym okresie. Grupa B zawiera też regiony względnie bogate, lecz o gorszych wynikach gospodarczych od grupy A. Do grupy tej należą województwa: śląskie, pomorskie i zachodniopomorskie. Cechuje je wyższy od średniej poziom PKB w wyjściowym okresie, ale rozwijają się wolniej od grupy A. Grupa C obejmuje obok województwa lubuskiego także województwa kujawsko-pomorskie, opolskie, warmińsko-mazurskie i świętokrzyskie. Scharakteryzować je należy jako odstające i o gorszych wynikach gospodarczych od spodziewanych. Mają one PKB niższe niż średnia krajowa i rozwijają się powoli. Grupa D zawiera także regiony odstające, lecz rozwijające się względnie dynamicznie. Szczególnie dotyczy to województw łódzkiego i małopolskiego. Oprócz nich do tej grupy należą także województwa podlaskie, podkarpackie i lubelskie.

\section{PODSUMOWANIE}

Ze względu na wielkość, położenie geograficzne, wysokość wynagrodzeń i przewagę tendencji do odpływu ludności nad tendencją do jej napływu województwo lubuskie charakteryzują procesy typowe dla regionów peryferyjnych. Przyczyny tego stanu to także jakość infrastruktury regionalnej, a w tym zaplecza badawczo-rozwojowego oraz rozwój szkolnictwa wyższego. Biorąc pod uwagę ścianę zachodnią kraju, można stwierdzić, że województwo lubuskie pozostaje niejako na uboczu względem takich regionów, jak województwa dolnośląskie i wielkopolskie. Świadczy o tym w szczególności poziom PKB na mieszkańca.

Z drugiej strony, ważnym czynnikiem rozwoju w regionie jest sektor małych i średnich przedsiębiorstw, szczególnie rozpatrując potencjał ilościowy tego sektora i jego udział w zatrudnieniu. Mniejszy niż ogólnie w kraju jest udział w zatrudnieniu dużych przedsiębiorstw. Drugi ważny czynnik stanowi liczna na tle danych dla kraju grupa podmiotów z udziałem kapitału zagranicznego. Podmioty te przyczyniają się do napływu kapitału zewnętrznego i także tworzą miejsca w pracy w regionie. Istotnym czynnikiem są również walory turystyczne województwa. Wśród walorów tych wymienić można: dużą lesistość, liczne jeziora i szlaki turystyczne. Liczba noclegów udzielonych turystom w regionie wskazuje, że czynnik ten nie w pełni jest wykorzystany. Ważnym zagadnieniem jest także problematyka wielofunkcyjnego rozwoju wsi i rolnictwa. W tym względzie barierami rozwoju są wyposażenie gospodarstw w ciągniki rolnicze i niski udział ludności mieszkającej na obszarach wiejskich w życiu społecznym regionu.

\section{LITERATURA}

Bajerski Artur, 2008: Problemy wydzielania peryferii spoleczno-gospodarczych, „Ruch Prawniczy, Ekonomiczny i Socjologiczny", z. 2, s. 159-167.

BDL (Bank Danych Lokalnych) GUS, dostęp: 20.09.2016, http://stat.gov.pl.

Domański Ryszard, 2006: Gospodarka przestrzenna. Podstawy teoretyczne, Wydawnictwo Naukowe PWN, Warszawa.

GUS, 2015a: Działalność gospodarcza podmiotów z kapitałem zagranicznym w 2014 roku, Warszawa. GUS, 2015b: Dziatalność przedsiębiorstw niefinansowych w 2014 roku, Warszawa.

GUS, 2016a: Rocznik statystyczny pracy 2015, Warszawa.

GUS, 2016b: Obszary wiejskie w Polsce w 2014 r., Warszawa, Olsztyn.

Grosse Tomasz Grzegorz, 2007: Wybrane koncepcje teoretyczne i doświadczenia praktyczne dotyczace rozwoju regionów peryferyjnych, „Studia Regionalne i Lokalne”, 1(27), s. 27-49. 
KE (Komisja Europejska), 2011: Polityka spójności 2014-2020. Inwestycje w rozwój gospodarczy i wzrost zatrudnienia, Dyrekcja Generalna ds. Polityki Regionalnej, Komisja Europejska, Luksemburg.

Korenik Stanisław, 1999: Rozwój regionu ekonomicznego na przykładzie Dolnego Śląska, Wydawnictwo Akademii Ekonomicznej we Wrocławiu, Wrocław.

Korol Janusz, 2007: Wskaźniki zrównoważonego rozwoju w modelowaniu procesów regionalnych, Wydawnictwo Adam Marszałek, Toruń.

Kosiedowski Wojciech, 2001: Teoretyczne problemy rozwoju regionalnego, [w] Zarzadzanie rozwojem regionalnym i lokalnym. Problemy teorii i praktyki, Wydawnictwo TNOiK, Torun, s. 17-43.

Kuciński Kazimierz (red.), 2015: Geografia ekonomiczna, Oficyna Wolters Kluwer Business, Warszawa.

Łaźniewska Ewa, 2013: Konkurencyjność regionalna w czasie i przestrzeni na przykładzie polskich regionów, Wydawnictwo Uniwersytetu Ekonomicznego w Poznaniu, Poznań.

Malina Anna, 2004: Wielowymiarowa analiza przestrzennego zróżnicowania struktury gospodarki Polski wedtug województw, Wydawnictwo Akademii Ekonomicznej w Krakowie, Kraków.

Miszczuk Andrzej, 2013: Uwarunkowania peryferyjności regionu przygranicznego, Wydawnictwo Norbertinum, Lublin.

Strahl Danuta (red.), 2006: Metody oceny rozwoju regionalnego, Wydawnictwo Uniwersytetu Ekonomicznego we Wrocławiu, Wrocław.

Strategia rozwoju województwa lubuskiego 2020, 2012: Załącznik do Uchwały Sejmiku Województwa Lubuskiego z dnia 19 listopada 2012 r., Zielona Góra.

Strategia energetyki województwa lubuskiego 2013: Załącznik pt. „Analiza stanu istniejącego systemów energetycznych", Energoekspert Sp. z o.o. Katowice.

Szymla Zygmunt, 2000: Determinanty rozwoju regionalnego, Akademia Ekonomiczna w Krakowie, Zakład Narodowy im. Ossolińskich, Wrocław.

US w Zielonej Górze, 2015: Rocznik statystyczny województwa lubuskiego 2015, Zielona Góra.

US w Zielonej Górze, 2016: Turystyka w województwie lubuskim w latach 2013-2015, Zielona Góra.

Zeliaś Aleksander (red.), 2000: Taksonomiczna analiza przestrzennego zróżnicowania poziomu życia w Polsce w ujęciu dynamicznym, Wydawnictwo Akademii Ekonomicznej w Krakowie, Kraków.

\section{Przemysław Szczuciński}

\section{DEVELOPMENT FACTORS, BARRIERS TO DEVELOPMENT AND PERIPHERALITY OF LUBUSKIE VOIVODESHIP}

\section{Summary}

The basic features of the contemporary economy include spatial diversity and its variation in time. It can be observed that some regions and countries develop faster and others slower. The theoretical framework of research into their development is specified by the concept of regional peripherality. In line with this concept, the possibilities for development of Lubuskie Voivodeship were assessed in the article. There were 39 diagnostic indicators considered in empirical research, describing the following groups of determinants: geographical location and settlement system, economy and its structure, demographical and social factors as well as infrastructure of the region. With the use of the data for 2014, the analysis of the voivodeship development was carried out in relation to Polish economy. Selected aspects of development of rural areas were considered. The results of the research indicate that Lubuskie Voivodeship is in many cases characterized by processes typical for peripheral regions.

Adres do korespondencji:

Dr Przemysław Szczuciński

Akademia im. Jakuba z Paradyża w Gorzowie Wlkp., Wydział Ekonomiczny ul. F. Chopina 52, 66-400 Gorzów Wlkp. e-mail: pszczucinski@pwsz.pl 